\title{
Comparison of the differences in the composition of ruderal flora between conventional tram tracks and managed green tram tracks in the urban ecosystem of the city of Bratislava
}

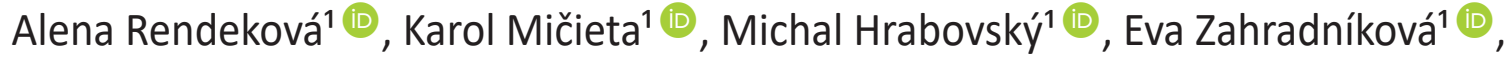 \\ Martina Michalová1, Ján Miškovic ${ }^{1}$, Mariana Eliašováa \& Dominika Ballová3
}

Key words: Central Europe, diversity, green infrastructure, invasive alien species, landscape planning, neophytes.

Ključne besede: Srednja Evropa, raznovrstnost, zelena infrastruktura, invazivne tujerodne vrste, krajinsko načrtovanje, neofiti.

Corresponding author:

Alena Rendeková

E-mail: alenarendekova@gmail.com

Received: 13. 5. 2021

Accepted: 24. 8. 2021

\begin{abstract}
Green infrastructure (GI) brings many benefits to urban ecosystems. Green tram tracks can be considered to be a part of GI. The presented study is focused on the comparison of the species' frequency and composition between conventional tram tracks and green tram tracks in Bratislava, Slovakia, Central Europe. This comparison also provides an insight into the changes of the flora of tram tracks over time, as we compare the results of the older research with recent research on green tram tracks. The results revealed significant differences in the composition of flora between conventional tram tracks and green tram tracks. In particular, the total number of species has decreased over time, as green tram tracks host fewer spontaneously growing taxa than conventional ones. The frequency of occurrence of archaeophytes and neophytes has decreased on the strict rail yard while on the tracksides it has increased. Green tram tracks deliver positive features to ecosystems, but may also have negative aspects because they present a pool of alien, potentially invasive plants.

Izvleček

Zelena infrastuktura (ZI) prinaša urbanim ekosistemom številne koristi. Med ZI lahko uvrščamo tudi zelene tramvajske proge. V raziskavi smo se osredotočili na primerjavo frekvenc ruderalnih rastlinskih vrst in vrstne sestave med konvencionalnimi tramvajskimi progami z ozelenjenimi v Bratislavi (Slovaška, srednja Evropa). Primerjava omogoča tudi vpogled v spremembe flore tramvajskih prog v času, saj smo primerjali razultate s starejšimi raziskavami. Razlike med konvencionalnimi in ozelenjenimi progami so bile statistično značilne. Število vrst se je s časom zmanjšalo, saj je na ozelenjenih progah manj vrst kot na konvencionalnih. Frekvenca pojavljanja arheofitov in neofitov se je zmanjšala med tračnicami, na robovih prog pa se je povečala. Ozelenjene tramvajske proge imajo za ekosisteme določeno pozitivno vlogo, vendar imajo tudi slabe lastnosti, saj predstavljajo nabor tujerodnih vrst, ki so potencialno invazivne.
\end{abstract}

1 Department of Botany, Faculty of Natural Sciences, Comenius University in Bratislava, Bratislava, Slovakia.

2 Department of Ecology, Slovak University of Agriculture, Nitra, Slovakia.

3 Department of Mathematics and Descriptive Geometry, Faculty of Civil Engineering, Slovak University of Technology in Bratislava, Bratislava, Slovakia. 


\section{Introduction}

With more and more people living in cities, a specific urban environment is emerging in more places across the world. The urbanisation in the past centuries has resulted in the reduction of natural habitats and biodiversity loss (Williams et al., 2009). Maintenance of remaining biodiversity in urban ecosystems and creating the most healthy environment possible for the citizens have became priority issues to be addressed by many environmentalists and other scientists, such as Williams et al. (2009), Burgin (2016), Horák et al. (2016), Kumar \& Verma (2017), Castro et al. (2020).

One of the valuable tools in this effort is green space planning and creation of green spaces and green infrastructure (GI), which helps to maintain clean air and better water quality, reduce pollutants, and mitigate noise, promote positive emotions in city' residents, and has other beneficial functions in urban areas (Provendier \& Damas, 2010; Steckler et al., 2012; Schreiter \& Kappis, 2013a, b; Wagner et al., 2013; Eglinton, 2014; Renterghemi et al., 2015; Sikorski et al., 2018; Cameron et al., 2020; Sikorska et al., 2020). Green infrastructure (GI) consists of the network of natural and human-made features, such as land reserves, parks, green roofs, eco-ducts, cycle paths and other features covered by specific species of plants (Andreuci, 2013).

Plants have always represented an important component of the urban environment. Spontaneously growing ruderal plants occur in many urban habitats, and ornamental plants have always been planted in public spaces, gardens, parks, and cemeteries (Wagner et al., 2013). The managed green spaces are perceived more positively by the city residents than unmaintained areas with ruderal weeds or sites without plants (Sikorski et al., 2018). The idea of green space planning came about precisely thanks to the effort to introduce more managed green spaces to the cities. While the first ideas in this area arose more than 100 years ago (Zube, 1995; Vasas et al., 2009), GI is still a relatively new area of interest in Europe (Andreuci, 2013) and the number of studies focused on it should be increased.

One of the important factors influencing the city environment is public transport. With the increasing number of people living in cities, demands for more efficient ways of public transport emerged. In the context of the reduction of negative environmental impacts of travelling, tram transport appears to be one of the most suitable solutions compared to buses and other ways of transport (Sikorski et al., 2018). There is a readily apparent trend of the increasing numbers of tramlines in many countries (e.g., Germany, Poland, Czech Republic, Switzerland, Neth- erlands, Belgium, Bulgaria, France, Italy, Spain, USA) (Henze \& Model, 2006; Banister, 2010; Eglinton, 2014; Pfautsch \& Howe, 2018). Ecological aspects are being increasingly taken into account more and more in tracks and railway construction (Steckler et al., 2012). Tram and railway tracks can serve as additional green spaces in builtup areas of cities if they are converted into 'green tracks' by replacing concrete between rails or ruderal weed vegetation on tracks by green carpets with planted vegetation (Sikorski et al., 2018). The plants which appear to be the most suitable for the greening of tracks are grasses and succulents, although in some cases herbaceous plants are also used (Steckler et al., 2012; Schreiter \& Kappis, 2013a, b; Eglinton, 2014; Sikorski et al., 2018).

Although green infrastructure features consist mainly of non-linear green spaces (Andreuci, 2013), green tram and railway tracks can be considered as the part of the GI concept, as they provide multiple environmental, health, social and economic benefits and functions, e.g., noise reduction, improvement of the microclimate (via reduction of heat island effect etc.), water retention, dust absorption, and uptake of contaminants (Schreiter, 2010; Schreiter \& Kappis, 2013a; Eglinton, 2014).

Green tram and railway tracks have been recently introduced in many European cities, and this has inspired research into this unique biotope. Consequently, recent years have seen the appearance of publications focusing on this area (Müller et al., 2001; Schreiter, 2010; Steckler et al., 2012; Schreiter \& Kappis, 2013a, b; Eglinton, 2014; Pfautsch \& Howe, 2018; Sikorski et al., 2018). In the majority of studies, green tram and railway tracks were researched separately from the spontaneously growing flora and vegetation of conventional tracks, or authors did not focus primarily on the comparison of these two types of habitats (Niemi, 1969; Suominen, 1969; Eliášs, 1979, 1981; Brandes, 1983, 1984, 1993a, b; Hohla et al., 2000, 2002; Brandes, 2002a, b, 2003, 2004a, b, c, d, 2005a, b, 2008; Jehlík \& Dostálek, 2008; Tret'yakova, 2010; Galera et al., 2012, 2014; Sudnik-Wójcikowska et al., 2014; Wierzbicka et al., 2014; Májeková et al., 2014; Májeková \& Limánek, 2016; Májeková et al., 2016; Woźnica et al., 2016; Wrzesień et al., 2016; Májeková et al., 2021). Sikorski et al. (2018) compared green tram tracks at different developmental stages from their establishment, but there is a lack of other similar studies, not to mention studies focused strictly on the comparison of conventional and green tracks. The findings of such study can be a valuable tool in landscape planning, and information about floristic differences between these two types of tracks can facilitate the management of urban flora and vegetation as well as biodiversity conservation. For this reason our research is focused on this issue. 
Until 2019, only spontaneously growing flora and vegetation occurred on tram tracks in Bratislava (Rendeková et al., 2020). In 2019, some parts of the tram tracks of Bratislava were repaired and at the end of October 2019, they were covered by planted succulents, mostly various taxa of the genus Sedum and tracksides were covered by various ornamental plants.

The aim of this study was to compare the number of species, frequency of their occurrence and species composition of the spontaneously growing ruderal flora between the past (i.e. conventional tram tracks) and present (i.e. green tram tracks). Specifically, we set up the following aims: (1) to record the species composition of the flora growing spontaneously on green tram tracks; (2) to analyse the differences in the total number of species, and a number of native species, archaeophytes, and neophytes; (3) to analyse the differences in the frequency of occurrence, i.e. the number of localities of all taxa, native taxa, archaeophytes, and neophytes; (4) to analyse the differences in the species composition of the flora of tram tracks, comparing the past and present by means of cluster analysis.

\section{Methods}

\section{Study area and data sampling}

The study builds on our previous research published by Rendeková et al. (2020), which was carried out in the years 2014-2019. The recent research was performed during the vegetation season of the year 2020. Both, the older and the more recent data were collected in the area of tram infrastructure of Bratislava, the capital city of Slovakia. It is situated in south-western Slovakia, Central Europe. The climate is continental and has a moderate to warm character. Bratislava belongs to the warmest and driest parts of Slovakia. Its area is $367.9 \mathrm{~km}^{2}$ and it has approximately 425,500 inhabitants.

Thanks to this relatively high number of city residents, efficient ways of public transportation are required. Tram transport solves part of this problem and represents the major component of public transport in Bratislava. The total length of the tram network of the city is $42 \mathrm{~km}$ (Feráková \& Jarolímek, 2011; Hrnčiarová et al., 2006). Until 2019, only spontaneously growing ruderal flora and vegetation occurred on some parts of the tram lines (Figure 1a), while other parts were covered by concrete (Rendeková et al., 2020). At the end of the October 2019, some parts of them were converted into green tram tracks (Figure $1 \mathrm{~b}$ ) by replacing spontaneously growing
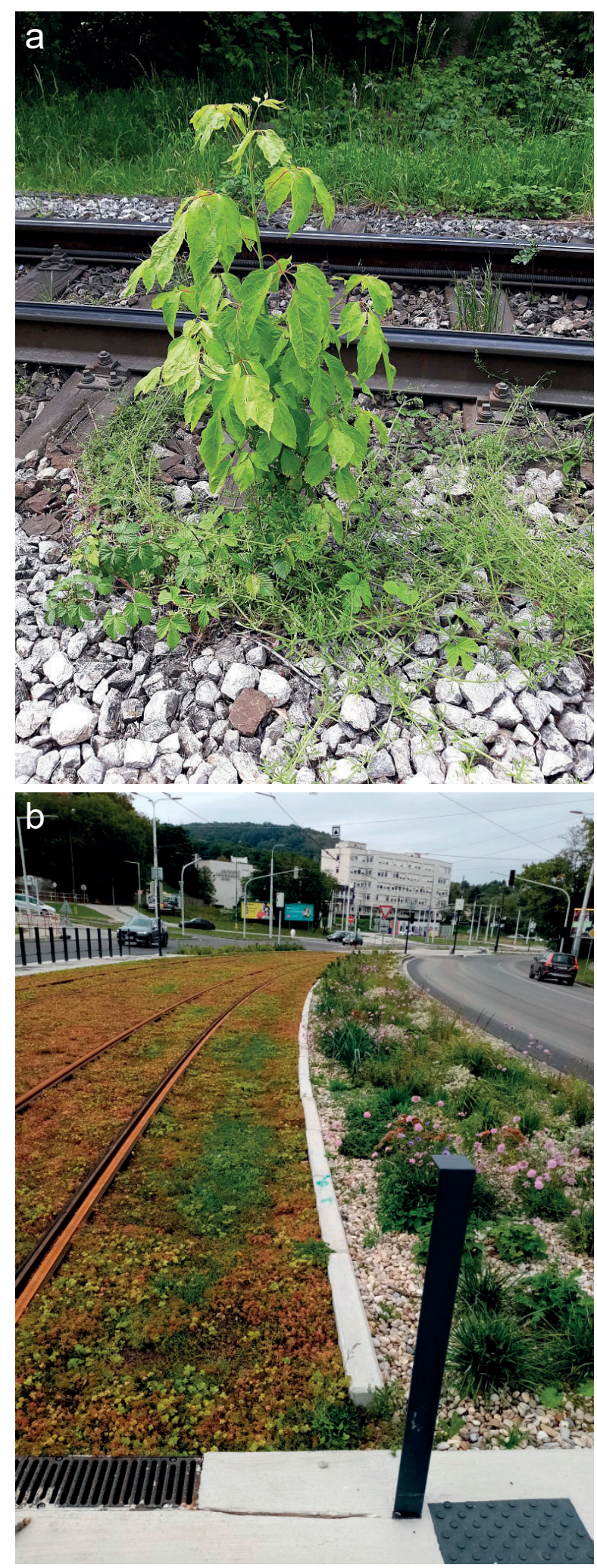

Figure 1: Photos showing the comparison between conventional tracks of Bratislava in the years 2014-2019 (a) and green tram tracks in 2020 (b) Slika 1: Primerjava med običajnimi progami v Bratislavi med leti 2014 in 2019 (a) in zelenimi tramvajskimi progami leta 2020 (b). 
flora with planted succulents, mostly various taxa of the genus Sedum. Tracksides were also re-built, and were covered by new, mostly gravelly substrate with various ornamental taxa (Figure 1b).

The tram network of Bratislava with marked survey plots is shown in Figure 2a. Of the 30 localities previously studied (Rendeková et al., 2020), 15 of the strict rail yard plots (areas between rails up to $0.5 \mathrm{~m}$ from the outer rail of tracks) have been converted into green tram tracks, i.e. covered by planted succulents (Figure 2b), and the current research was carried out on these localities. On 10 of the selected 15 localities, the tracksides (plots running from $0.5 \mathrm{~m}$ to $3 \mathrm{~m}$ from the outer rail of the tracks) were also covered by planted ornamental plants (Figure 2c). We have also recorded plant taxa on the tracksides here. Some parts of the tracks remained covered by concrete (2d); the survey was not performed here. Plot sizes were $2 \times 2.5 \mathrm{~m}^{2}$, as in the previous study of Rendeková et al. (2020). We chose this size because it is the same as in the previous study, to make the past and present data better comparable. The locations of the plots are presented in Table 1. Some of tram stops have been renamed; we present the new names in Table 1.
We recorded the presence/absence of plants growing spontaneously on the tram tracks. In addition, Greenfond Polska Sp z o.o. and METRO Bratislava a.s., the groups which have carried out the 'greening' process of Bratislava's tram tracks, have provided us with lists of species planted on the tram tracks. While we also recorded the planted taxa from these lists, which were growing on the researched plots, these were not included into analyses, as the aim of the research was to study the changes in the spontaneously growing ruderal flora. Bryophytes were also recorded, but not included in the analyses because of their uncertain origin status. In order to provide a complete picture of tram track flora, we also present planted taxa and bryophytes in the lists of recorded taxa (Tables 2-3)

Taxa were recorded three times at each plot: 1) from April to the beginning of June, 2) from the end of June to the beginning of August, 3) at the end of August, and in September. This enabled us to record various stages of development of the flora. The same approach was applied in the previous study od Rendeková et al. (2020). In the previous study, we did not sample each locality every year between 2014-2019, each locality was sampled only in one year.
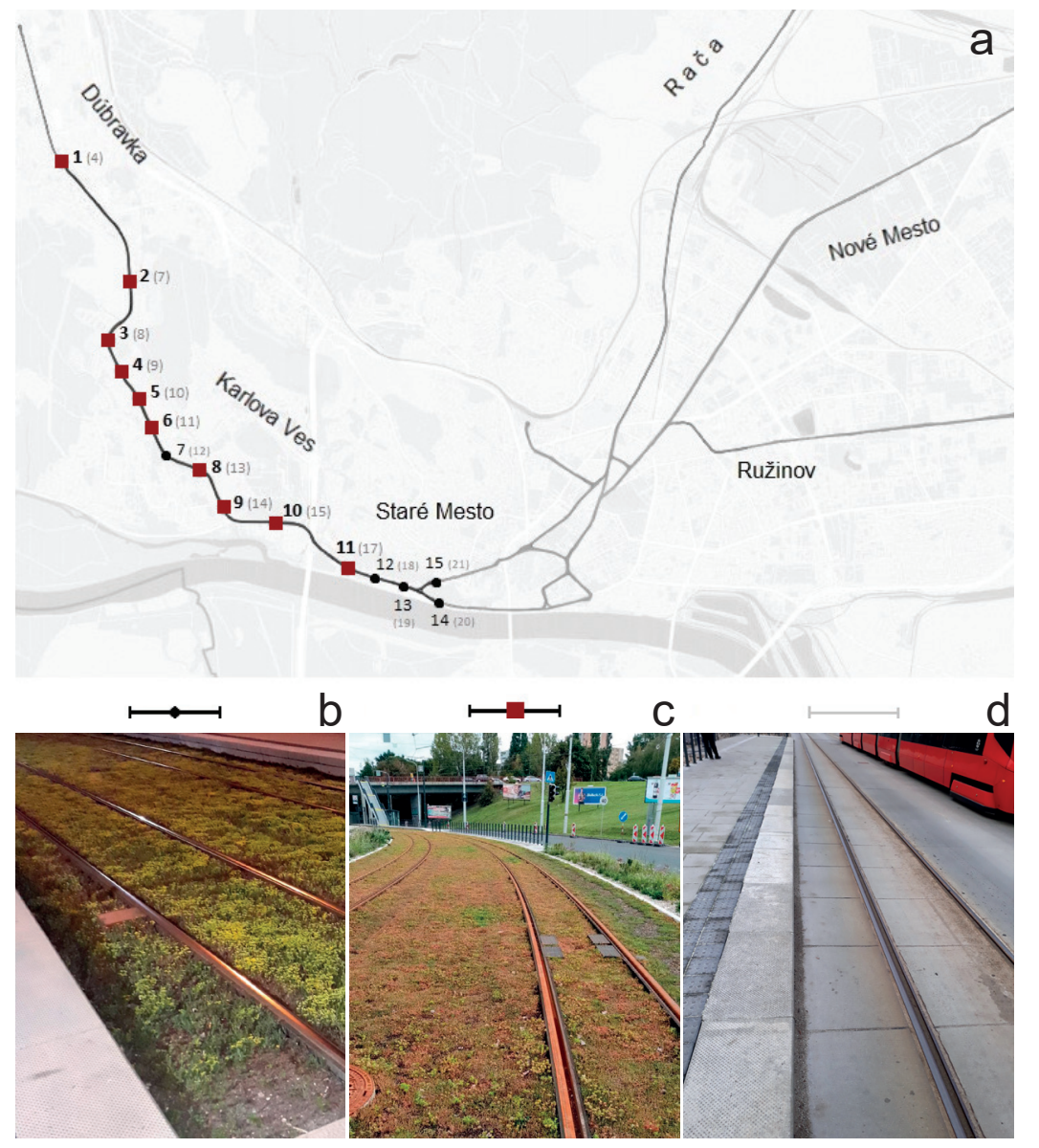

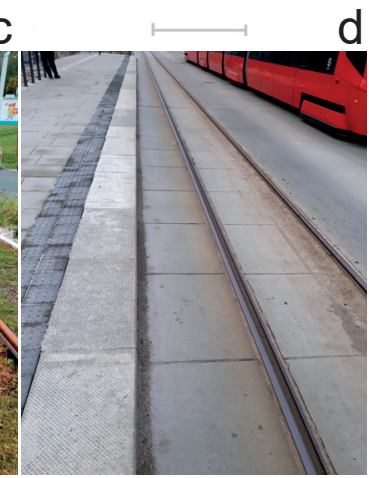

Figure 2: Tram network of Bratislava with marked survey plots (a). Explanation: numbers represent numbers of survey plots described in Table 1; numbers in brackets represent plots' numbering in the past - i.e. in the work of Rendeková et al. (2020); black line colour represents parts of tram tracks, where plants grew and where the research was done; black circles represent plots, where only strict rail yard was researched (b); red squares represent plots, where also tracksides were researched (c); grey line colour represents parts of tram tracks completely covered by concrete without flora and vegetation, which were excluded from the research (d).

Slika 2: Mreža tramvajskih prog Bratislave z označenimi popisnimi ploskvami (a). Legenda: številke predstavljajo število popisnih ploskev opisanih v Tabeli 1 ; številke v oklepajih predstavljajo oštevilčenje v preteklosti- t.j. v članku Rendeková et al. (2020); črne črte predstavljajo tramvajske proge, kjer uspevajo rastline in smo izvedli vzorčenje; črni krožci predstavljajo ploskve, kjer smo popisovali samo med tračnicami (b); rdeči kvadratki predstavljajo ploskve, kjer smo vzorčili tudi robove prog (c); sive črte predstavljajo dele prog popolnoma prekritih z betonom brez flore in vegetacije, ki smo jih izločili iz raziskav (d). 
Table 1: Locations of the survey plots.

Tabela 1: Lokacije popisnih ploskev.

\begin{tabular}{|c|c|c|c|}
\hline $\begin{array}{l}\text { Number } \\
\text { of locality }\end{array}$ & $\begin{array}{l}\text { Number of locality in the past } \\
\text { [Rendeková et al. (2020)] }\end{array}$ & Description of locality & GPS coordinates \\
\hline 1 & 4 & $\begin{array}{l}\text { Bratislava, Dúbravka, tram track near Švantnerova street, } 8 \mathrm{~m} \\
\text { from the tram stop Švantnerova }\end{array}$ & $\begin{array}{l}\text { N } 48^{\circ} 10^{\prime} 57.40^{\prime \prime} \\
\text { E } 17^{\circ} 02^{\prime} 21.60^{\prime \prime}\end{array}$ \\
\hline 2 & 7 & $\begin{array}{l}\text { Bratislava, Karlova Ves, tram track at the crossroad of the streets } \\
\text { Karloveská } \times \text { Svíbová }\end{array}$ & $\begin{array}{l}\text { N } 48^{\circ} 09^{\prime} 56.30^{\prime \prime}, \\
\text { E } 17^{\circ} 02^{\prime} 46.60^{\prime \prime}\end{array}$ \\
\hline 3 & 8 & $\begin{array}{l}\text { Bratislava, Karlova Ves, tram track along the Karloveská street, } \\
25 \text { m from the tram stop Kútiky }\end{array}$ & $\begin{array}{l}\mathrm{N} 48^{\circ} 09^{\prime} 53.30^{\prime \prime} \\
\mathrm{E} 17^{\circ} 02^{\prime} 48.30^{\prime \prime}\end{array}$ \\
\hline 4 & 9 & $\begin{array}{l}\text { Bratislava, Karlova Ves, tram track at the crossroad of the streets } \\
\text { Karloveská } \times \text { Borská, } 8 \mathrm{~m} \text { from the tram stop Borská }\end{array}$ & $\begin{array}{l}\text { N } 48^{\circ} 09^{\prime} 44.60 ", \\
\text { E } 17^{\circ} 02^{\prime} 54.10^{\prime \prime}\end{array}$ \\
\hline 5 & 10 & $\begin{array}{l}\text { Bratislava, Karlova Ves, tram track at the crossroad of the streets } \\
\text { Karloveská } \times \text { Lackova }\end{array}$ & $\begin{array}{l}\mathrm{N} 48^{\circ} 09^{\prime} 32.30^{\prime \prime}, \\
\mathrm{E} 17^{\circ} 03^{\prime} 04.90^{\prime \prime}\end{array}$ \\
\hline 6 & 11 & $\begin{array}{l}\text { Bratislava, Karlova Ves, tram track near Kempelenova street, } \\
4 \mathrm{~m} \text { from the tram stop Nad lúčkami }\end{array}$ & $\begin{array}{l}\mathrm{N} 48^{\circ} 09^{\prime} 21.50^{\prime \prime} \\
\mathrm{E} 17^{\circ} 03^{\prime} 12.20^{\prime \prime}\end{array}$ \\
\hline 7 & 12 & $\begin{array}{l}\text { Bratislava, Karlova Ves, tram track along the Segnerova street, } \\
10 \mathrm{~m} \text { from the tram stop Segnerova }\end{array}$ & $\begin{array}{l}\text { N } 48^{\circ} 09^{\prime} 13.60^{\prime \prime}, \\
\text { E } 17^{\circ} 03^{\prime} 26.90^{\prime \prime}\end{array}$ \\
\hline 8 & 13 & Bratislava, Karlova Ves, tram track near Jurigovo námestie street & $\begin{array}{l}\text { N } 48^{\circ} 09^{\prime} 08.80^{\prime \prime}, \\
\text { E } 17^{\circ} 03^{\prime} 39.70^{\prime \prime}\end{array}$ \\
\hline 9 & 14 & $\begin{array}{l}\text { Bratislava, Karlova Ves, tram track along the Ladislava Sáru } \\
\text { street, } 25 \mathrm{~m} \text { from the tram stop Riviéra }\end{array}$ & $\begin{array}{l}\text { N } 48^{\circ} 08^{\prime} 59.30^{\prime \prime}, \\
\text { E } 17^{\circ} 03^{\prime} 46.30^{\prime \prime}\end{array}$ \\
\hline 10 & 15 & Bratislava, Karlova Ves, tram track near Na Riviére street & $\begin{array}{l}\text { N } 48^{\circ} 08^{\prime} 54.40^{\prime \prime} \\
\text { E } 17^{\circ} 03^{\prime} 50.20^{\prime \prime}\end{array}$ \\
\hline 11 & 17 & $\begin{array}{l}\text { Bratislava, Karlova Ves, tram track along the street Botanická, } \\
7 \mathrm{~m} \text { from the tram stop Botanická záhrada }\end{array}$ & $\begin{array}{l}\text { N } 48^{\circ} 08^{\prime} 53.80^{\prime \prime} \\
\text { E } 17^{\circ} 04^{\prime} 14.90^{\prime \prime}\end{array}$ \\
\hline 12 & 18 & $\begin{array}{l}\text { Bratislava, Staré Mesto, tram track at the crossroad of the } \\
\text { streets Nábrežie armádneho generála Ludvíka Svobodu } \times \text { Nad } \\
\text { lomom, } 14 \mathrm{~m} \text { from the tram stop Lanfranconi }\end{array}$ & $\begin{array}{l}\text { N } 48^{\circ} 08^{\prime} 43.40 ", \\
\text { E } 17^{\circ} 04^{\prime} 40.50^{\prime \prime}\end{array}$ \\
\hline 13 & 19 & $\begin{array}{l}\text { Bratislava, Staré Mesto, tram track along the Nábrežie } \\
\text { armádneho generála Ludvíka Svobodu street }\end{array}$ & $\begin{array}{l}\text { N } 48^{\circ} 08^{\prime} 33.60^{\prime \prime}, \\
\text { E } 17^{\circ} 05^{\prime} 10.10^{\prime \prime}\end{array}$ \\
\hline 14 & 20 & $\begin{array}{l}\text { Bratislava, Staré Mesto, tram track along the Dvořákovo } \\
\text { nábrežie street }\end{array}$ & 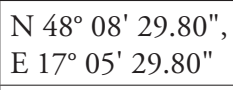 \\
\hline 15 & 21 & Bratislava, Staré Mesto, tram track 20 m from Žižkova street & $\begin{array}{l}\text { N } 48^{\circ} 08^{\prime} 31.60^{\prime \prime} \\
\text { E } 17^{\circ} 05^{\prime} 26.50^{\prime \prime}\end{array}$ \\
\hline
\end{tabular}

Explanation: numbers in bold represent numbers of survey plots, where also tracksides were resea

\section{Data analysis}

Analyses were only done for the spontaneously growing recorded taxa of vascular plants. The taxa were divided into native and alien. The second group was divided into archaeophytes and neophytes. The origin status of taxa follows the list of alien vascular plants of the Slovak Republic (Medvecká et al., 2012). The spontaneously growing ornamental alien taxa (i.e. ornamental taxa, which were not planted on tram tracks by Greenfond Polska Sp z o.o. and METRO, but appeared on tram tracks after being planted in nearby gardens and parks), which are not included in the list of alien plants (Medvecká et al., 2012), were evaluated as neophytes.
Analyses of the records from the strict rail yard and the records from tracksides were done separately. The reason for doing the analyses this way was that from the previous 30 localities (Rendeková et al., 2020), 15 strict rail yard plots were converted into green tram tracks, but only 10 trackside plots were covered by planted ornamental plants.

The changes in the total number of native taxa, archaeophytes and neophytes between the older and more recent datasets were evaluated by the creation of graphs in the program R 3.5.1. (R Core Team, 2018). The number of taxa which were recorded only in the past, only in the present, and in both periods, and the number of taxa for which the frequency of occurrence declined, increased or 
remained the same compared to the past were also evaluated in the same way.

In the statistical analyses, the normality of the data was tested by the Shapiro-Wilk test first. Since the data were not normally distributed, non-parametric analyses were used in the following steps.

The differences in the frequency of occurrence (i.e. the number of localities) of native taxa, archaeophytes and neophytes between the older and the more recent datasets were analysed by Sign test and by Wilcoxon two-sample test.

The binary distance and average linkage method were used in the cluster analysis. These parameters proved to be the best for both, the data from the strict rail yard and data from tracksides, after testing.

As explanatory feature, the changes in Raunkiær's life forms of recorded spontaneously growing taxa between the old and the more recent period was calculated. We calculated the frequency of occurrence (i.e. the number of localities) of each Raunkiær's life form in the old dataset and compared it with those of the more recent dataset by Wilcoxon test. The Raunkiær's life forms were determined according to the 'List of alien vascular plant species of the Slovak Republic' (Medvecká et al., 2012) and according to the Pladias - Database of the Czech Flora and Vegetation (Chytrý et al., 2021). The statistical analyses were done in the R 3.5.1. (R Core Team, 2018).

\section{Nomenclature}

The nomenclature of the taxa follows The Plant List (2013) and the nomenclature of the syntaxa follows Jarolímek et al. (2008).

\section{Results}

Both datasets together contained 123 taxa spontaneously growing on the strict rail yard of Bratislava tram tracks (Table 2) and 96 taxa spontaneously growing on tracksides (Table 3).

From the number of taxa spontaneously growing on strict rail yard habitat, 60 taxa (49\%) were only recorded in the older dataset (i.e. on conventional tram tracks), 23 (19\%) were only recorded in the more recent one (i.e. on green tram tracks), and $40(33 \%)$ were present in both (Figure 3). From the total number of species of the trackside habitat, 47 taxa (49\%) were only recorded in the past, 27 (28\%) were only recorded in the present, and $22(23 \%)$ were recorded in both periods (Figure 4$)$. In 2020 , planted taxa also grew on the tram tracks, and we recorded 17 of them on the strict rail yard (Table 2) and 31 on the tracksides (Table 3).

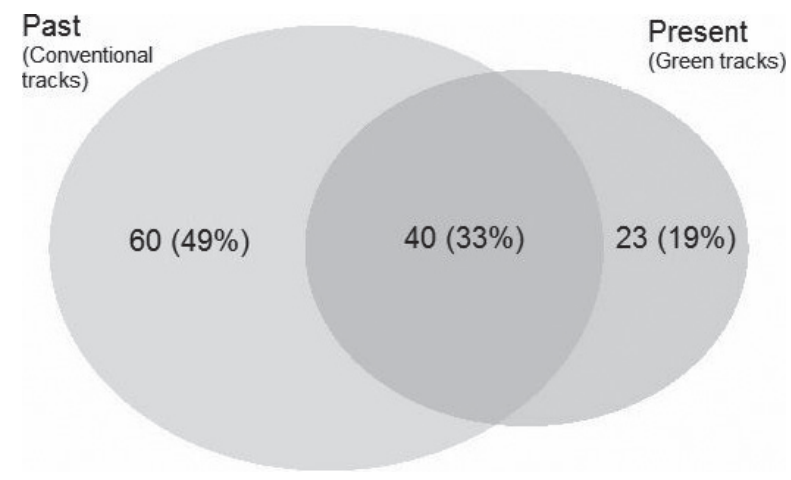

Figure 3: Venn diagram for the number and percentages of spontaneously growing ruderal plant taxa recorded on the strict rail yard of conventional tram tracks in the past (2014-2019) and green tram tracks in the present (2020).

Slika 3: Vennov diagram za število in odstotke spontano rastočih ruderalnih rastlinskih vrst med tračnicami na konvencionalnih tramvajskih progah v preteklosti (2014-2019) in ozelenjenih tramvajskih progah v sedanjosti (2020).

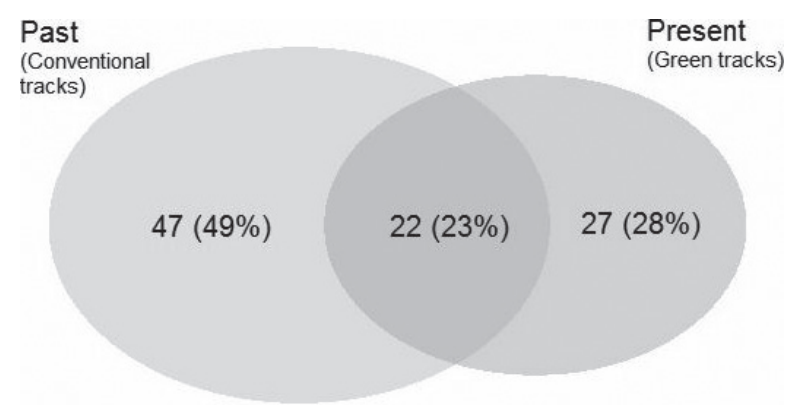

Figure 4: Venn diagram for the number and percentages of spontaneously growing ruderal plant taxa recorded on the tracksides of conventional tram tracks in the past (2014-2019) and green tram tracks in the present (2020)

Slika 4: Vennov diagram za število in odstotke spontano rastočih rudralnih rastlinskih vrst na robovih konvencionalnih tramvajskih prog v preteklosti (2014-2019) in ozelenjenih tramvajskih progah v sedanojsti (2020).

From the total number of species of the strict rail yard, there were 72 taxa (59\%) for which the frequency of occurrence (i.e. the number of localities) declined compared to the past, 41 taxa $(33 \%)$ for which the frequency of occurrence increased and 10 taxa $(8 \%)$ for which the frequency of occurrence was the same as in the past (Figure 5). On tracksides, the frequency of occurrence of 57 taxa (59\%) declined compared to the past, the frequency of occurrence of 35 taxa $(36 \%)$ increased and the frequency of occurrence of 4 taxa $(4 \%)$ was the same as in the past (Figure 6). 


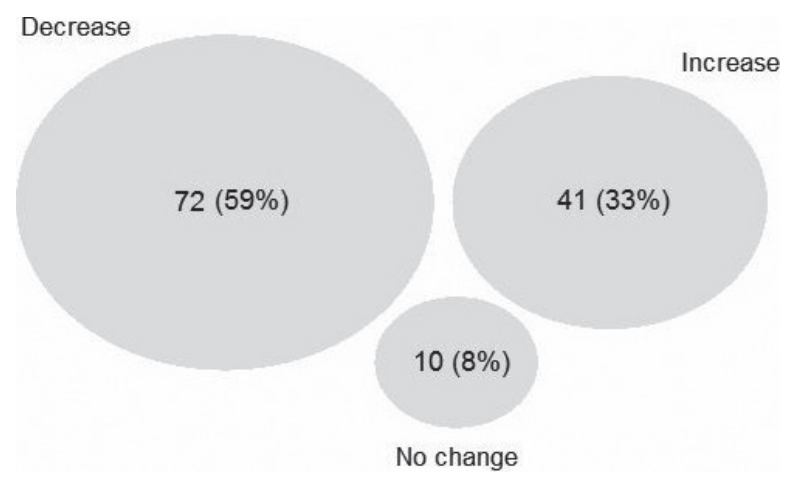

Figure 5: Venn diagram for changes in the frequency of occurrence (i.e. the number and percentages of localities) of taxa between strict rail yard of conventional tracks (past) and green tracks (present).

Slika 5: Vennov diagram frekvence pojavljanja (t.j. števila in odstotka lokacij) taksonov med tračnicami konvencionalnih prog (v preteklosti) in ozelenjenih prog ( $\mathrm{v}$ sedanjosti).

From the total number of plant species spontaneously growing on the researched plots of the strict rail yard in the past, 31 were archaeophytes, 25 were neophytes, and 44 were native (Figure 7). In 2020, the numbers in each of these groups were lower than in the past (18 archaeophytes, 11 neophytes, 34 native taxa) (Figure 7).

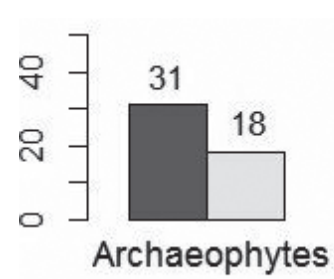

Archaeophytes

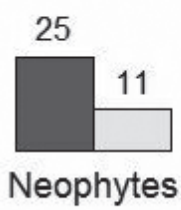

Past (Conventional tracks) Present (Green tracks)

Figure 7: Number of native taxa, archaeophytes and neophytes recorded on the strict rail yard of conventional tram tracks in the past (2014-2019) and green tram tracks in the present (2020)

Slika 7: Število domorodnih taksonov, arheofitov in neofitov med tračnicami konvencionalnih prog (v preteklosti) in ozelenjenih prog (v sedanjosti).

In the past, 15 taxa of archaeophytes, 5 taxa of neophytes and 49 native taxa grew on the tracksides (Figure 8). In 2020, the number of native species on tracksides was lower than in the past, as there were 17 native taxa recorded. The number of archaeophytes and neophytes on tracksides increased; we recorded 22 taxa of archaeophytes and 10 taxa of neophytes (Figure 8).

The differences between the older and more recent datasets from the strict rail yard for alien taxa were confirmed by statistical analyses (Sign test and Wilcoxon two-sample

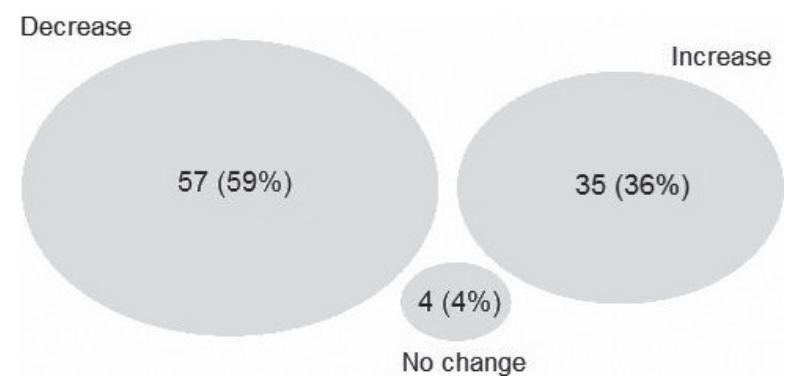

Figure 6: Venn diagram for changes in the frequency of occurrence (i.e. the number and percentages of localities) of taxa between tracksides of conventional tracks (past) and green tracks (present).

Slika 5: Vennov diagram sprememb frekvence pojavljanja (t.j. števila in odstotka lokalitet) taksonov med tračnicami konvencionalnih prog (v preteklosti) in ozelenjenih prog ( $\mathrm{v}$ sedanjosti).

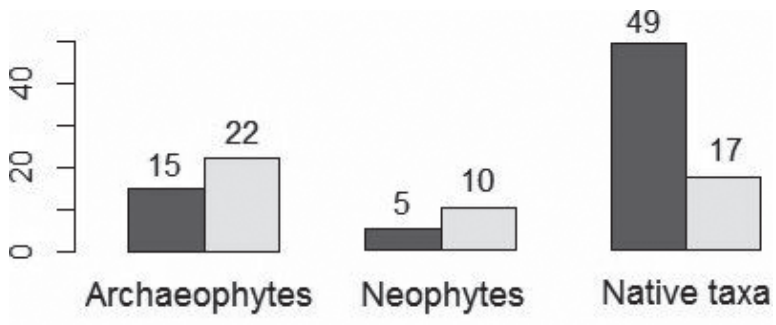

Past (Conventional tracks) Present (Green tracks)

Figure 8: Number of native taxa, archaeophytes and neophytes recorded on the tracksides of conventional tram tracks in the past (2014-2019) and green tram tracks in present (2020)

Slika 8: Število domorodnih taksonov, arheofitov in neofitov na robovih konvencionalnih prog (2014-2019) in ozelenjenih prog (2020).

test). The analyses revealed a statistically significant difference in the frequency of occurrence (i.e. the number of localities) of archaeophytes ( $\mathrm{W}=890, \mathrm{p}=0.005 ; \mathrm{S}=21$, $\mathrm{p}=0.020$ ). The number of localities of archaeophytes has decreased compared to the past (Figure 9a). The number of localities of neophytes also decreased with statistical significance $(\mathrm{W}=525.5, \mathrm{p}=0.003 ; \mathrm{S}=19, \mathrm{p}=0.007$ ) (Figure 9b). Analysis of the differences in the number of localities of native species did not reveal any significant differences $(\mathrm{W}=2060, \mathrm{p}=0.300 ; \mathrm{S}=32, \mathrm{p}=0.300$ ) (Figure 9c).

The Sign test and Wilcoxon two-sample test also revealed some differences in the frequency of occurrence of plant species on the tracksides. The number of trackside localities of archaeophytes increased with statistical significance compared to the past $(\mathrm{W}=215.5, \mathrm{p}=0.008$; $\mathrm{S}=8, \mathrm{p}=0.015$ ) (Figure 10a). The number of trackside 
a

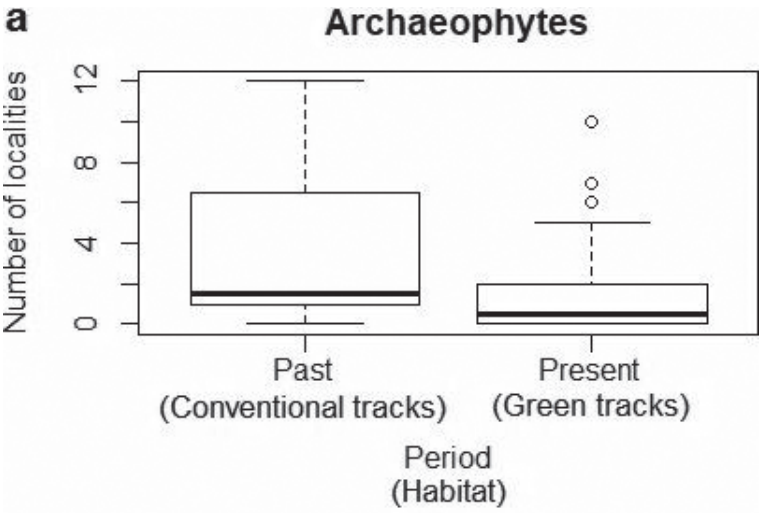

b

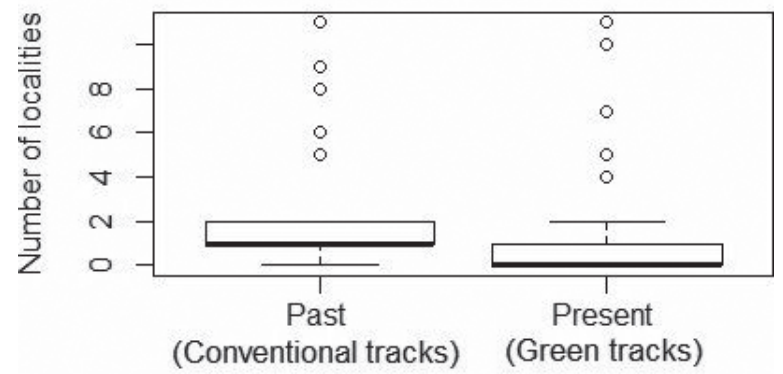

Period

(Habitat)

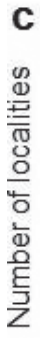

Native taxa

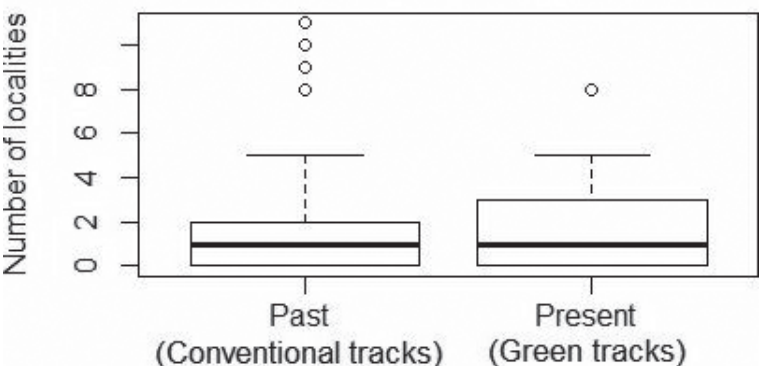

Period

(Habitat)

Figure 9: Comparison of the frequency of occurrence (i.e. the number of localities) of archaeophytes (a), neophytes (b), and native taxa (c) between strict rail yard of conventional tracks (past) and strict rail yard of green tracks (present). Explanation: - median, $\square$ 25\%-75\%, I minmax, $\circ$ outliers.

Slika 9: Primerjava frekvence pojavljanja (t.j. števila lokacij) arheofitov (a), neofitov (b) in domorodnih vrst (c) med tračnicami konvencionalnih prog (preteklost) in ozelenjenih prog (sedanjost). Legenda: mediana, $\square 25 \%$ 75\%, I min-max, ○ osamelci.

localities of neophytes also increased (Figure 10b), but this difference was not statistically significant $(\mathrm{W}=39.5$, $\mathrm{p}=0.054 ; \mathrm{S}=4, \mathrm{p}=0.388)$. The number of trackside a

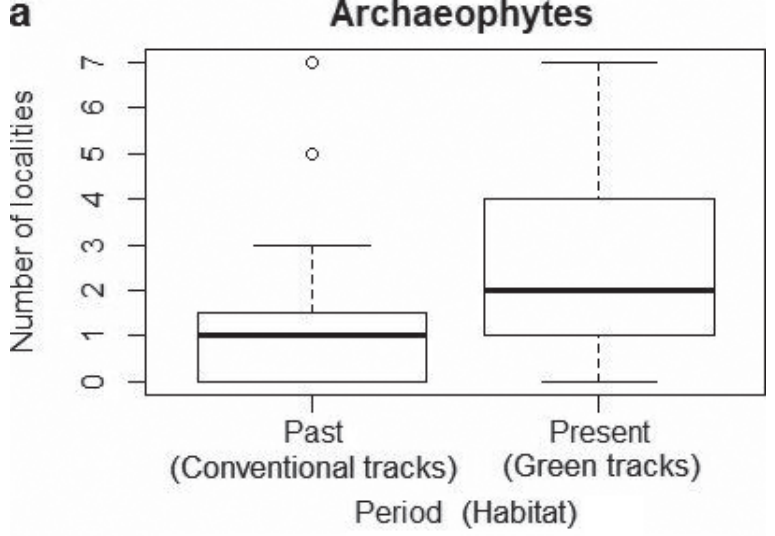

b

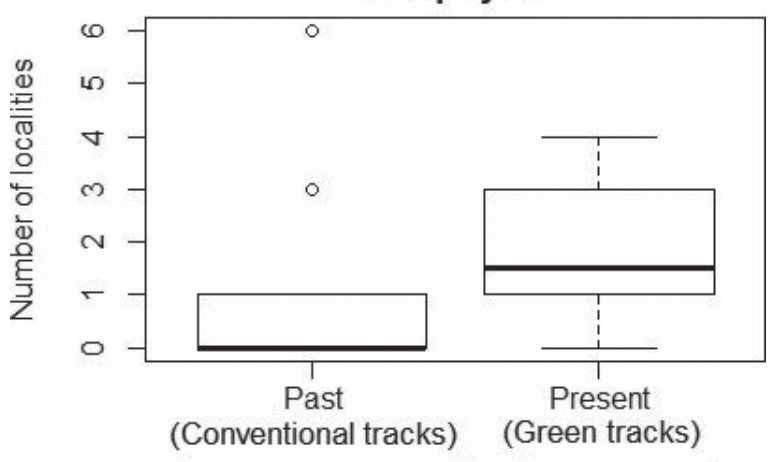

Period (Habitat)

c

Native taxa

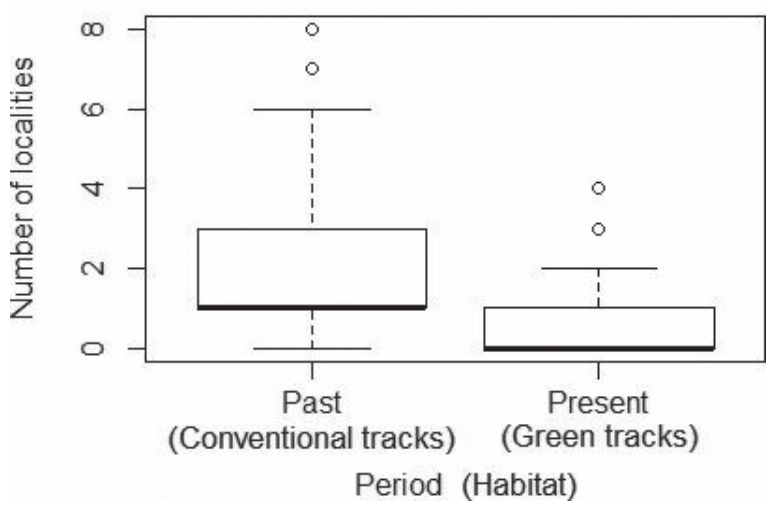

Figure 10: Comparison of the frequency of occurrence (i.e. the number of localities) of archaeophytes (a), neophytes (b), and native taxa (c) between tracksides of conventional tracks (past) and tracksides of green tracks (present). Explanation: - median, $\square$ 25\%-75\%, I minmax, ○ outliers

Slika 10: Primerjava frekvence pojavljanja (t.j. števila lokacij) arheofitov (a), neofitov (b) in domorodnih vrst (c) med robovi konvencionalnih prog (preteklost) in ozelenjenih prog (sedanjost). Legenda: - mediana, $\square$ 25\%-75\%, I min-max, o osamelci.

localities of native taxa decreased significantly compared to the past $(\mathrm{W}=2566, \mathrm{p}<0.001 ; \mathrm{S}=45, \mathrm{p}<0.001)$ (Figure 10c). 
We recorded the changes in the spectrum of the Raunkiær's life forms. The statistical analyses on the level of significance 0.1 revealed significant increase in the frequency of occurrence (i.e. the number of localities) of therophytes $(\mathrm{W}=2641.5, \mathrm{p}=0.071)$ and on the level of significance 0.05 significant decrease of hemicryptophytes $(\mathrm{W}=2497.5, \mathrm{p}=0.003)$ on the strict rail yard (Figure 11). Changes in other life forms on the strict rail yard were not statistically significant (geophytes: $\mathrm{W}=46$, $\mathrm{p}=0.118$; chamaephytes: $\mathrm{W}=4, \mathrm{p}=0.999$; phanerophytes: $\mathrm{W}=38, \mathrm{p}=0.110$ ).

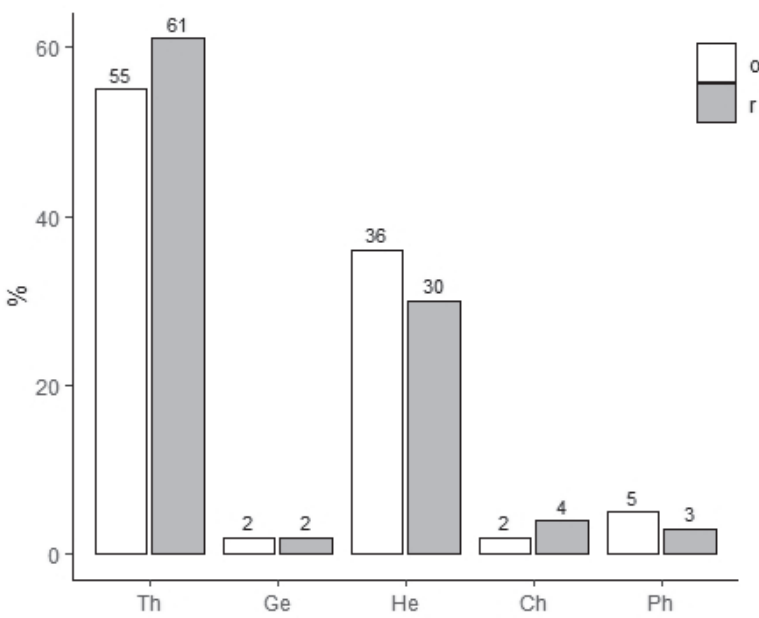

Figure 11: Comparison of the frequency of occurrence (i.e. the number of localities) of Raunkiær's life forms between strict rail yard of conventional tracks (old data) and strict rail yard of green tracks (recent data). Explanation: Th - therophytes, $\mathrm{Ge}$ - geophytes, $\mathrm{He}-$ hemicryptophytes, $\mathrm{Ch}$ - chamaephytes, $\mathrm{Ph}$ - phanerophytes, o - old data, $r$ - recent data.

Slika 11: Primerjava frekvence pojavljanja (t.j. števila lokacij) Raunkierjevih življenskih oblik med tračnicami konvencionalnih prog (stari podatki) in ozelenjenih prog (novi podatki). Legenda: Th - terofiti, Ge - geofiti, $\mathrm{He}$ - hemikriptofiti, Ch - hamefiti, Ph - fanerofiti, o - stari podatki, $\mathrm{r}$ - novi podatki.

The statistical analysis of the changes of Raunkiær's life forms on tracksides revealed significant increase in the frequency of occurrence (i.e. the number of localities) of therophytes $(\mathrm{W}=607.5, \mathrm{p}=0.011)$ and significant decrease of hemicryptophytes ( $\mathrm{W}=2076.5, \mathrm{p}<0.001$ ) on the level of significance 0.05 (Figure 12). Changes in other life forms on stracksides were not statistically significant (geophytes: $\mathrm{W}=37.5, \mathrm{p}=0.118$; chamaephytes: $\mathrm{W}=8.5, \mathrm{p}=0.999$; phanerophytes: $\mathrm{W}=27.5, \mathrm{p}=0.733$ ).

The cluster analysis also showed the differences between the past (conventional tracks) and present (green tram tracks) data. Figure 13 shows the results of the cluster analysis for the strict rail yard. Most of the records from the strict rail yard were separated based on the years in which they had been recorded. Most of the recent re-

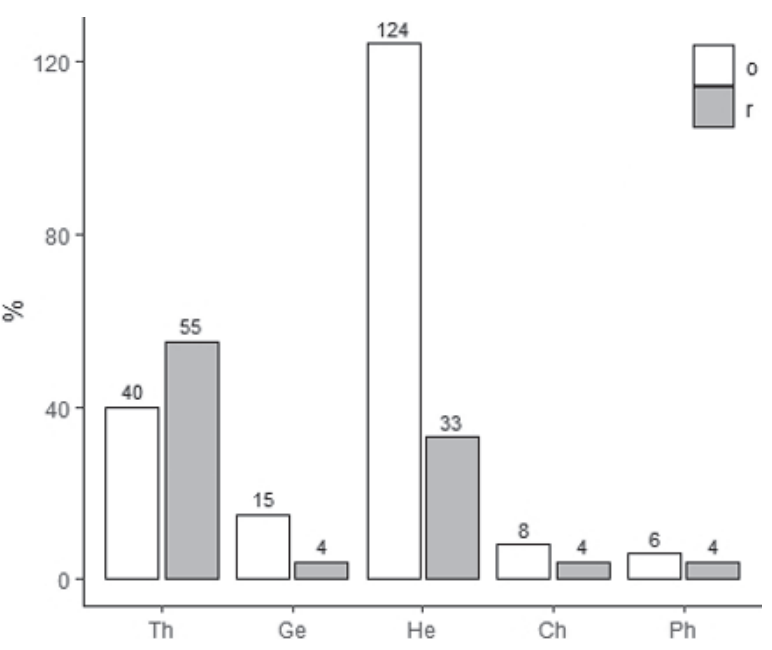

Figure 12: Comparison of the frequency of occurrence (i.e. the number of localities) of Raunkiær's life forms between tracksides of conventional tracks (old data) and tracksides of green tracks (recent data). Explanation: Th - therophytes, $\mathrm{Ge}$ - geophytes, $\mathrm{He}-$ hemicryptophytes, $\mathrm{Ch}$ - chamaephytes, $\mathrm{Ph}$ - phanerophytes, o - old data, $r$ - recent data

Slika 12: Primerjava frekvence pojavljanja (t.j. števila lokalitet) Raunkierjevih življenskih oblik med robovi konvencionalnih prog (stari podatki) in ozelenjenih prog (novi podatki). Legenda: Th - terofiti, Ge - geofiti, He - hemikriptofiti, Ch - hamefiti, Ph - fanerofiti, o - stari podatki, $\mathrm{r}$ - novi podatki.

cords were merged in the clusters A, C, D and E, whereas most of the records from the past were merged in the cluster B by hierarchical clustering (Figure 13).

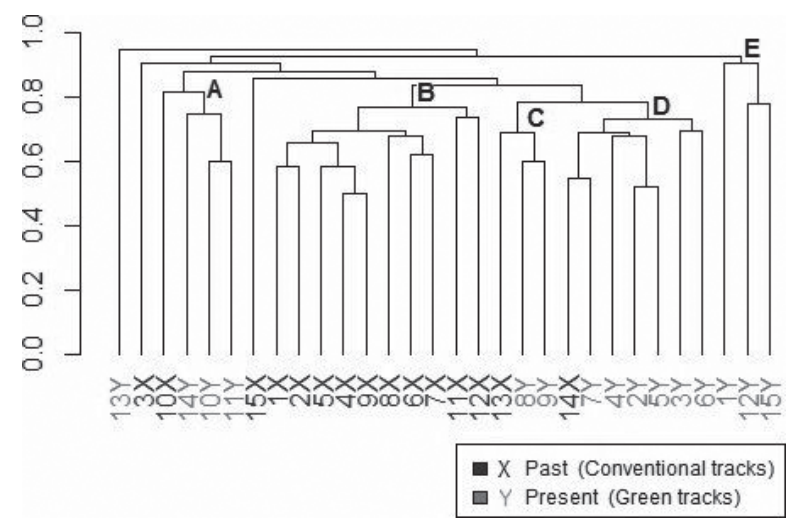

Figure 13: Dendrogram of cluster analysis of the flora of different strict rail yard localities (binary distance and average linkage method were used). Explanation: A, B, C, D, E - clusters A, B, C, D, E; X plots from conventional tracks recorded in the past (2014-2019), $\mathrm{Y}$ - plots from green tracks recorded in the present (2020), numbers represent numbers of localities - for explanation see Table 1 .

Slika 13: Dendrogram klastrske analize flore med tramvajskimi tračnicami na različnih lokacijah (uporabili smo binarno razdaljo in povprečno metodo povezovanja). Legenda: A, B, C, D, E - klastri A, B, C, D, E; X - ploskve na konvencionalnih progah med leti 2014 in 2019, Y - ploskve na ozelenjenih progah leta 2020, številka predstavlja število lokacij - za razlago glej Tabelo 1 . 
The results of the cluster analysis of records from the tracksides are shown in Figure 14. The records from the tracksides were separated into five clusters, most of which were formed based on the period in which the records were recorded. Clusters A and D predominantly merge the old records, cluster $\mathrm{C}$ the recent ones. Only cluster $\mathrm{B}$ contains both the old and the more recent trackside records (Figure 14).

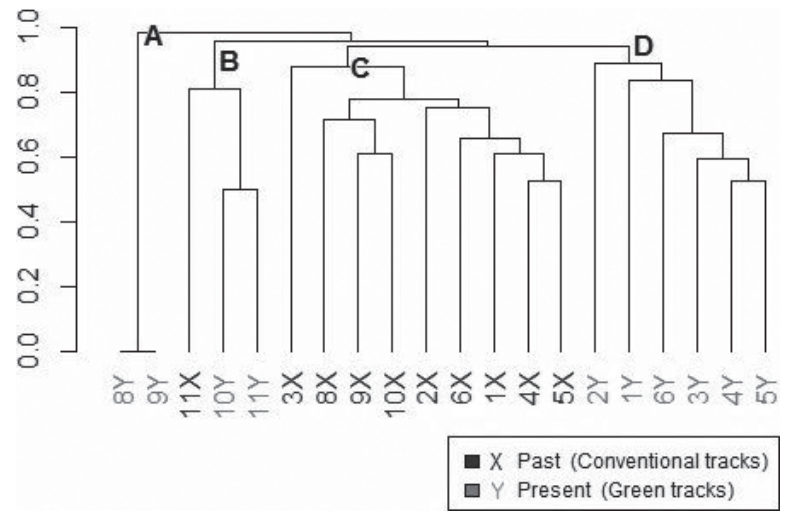

Figure 14: Dendrogram of cluster analysis of the flora of different trackside localities (binary distance and average linkage method were used). Explanation: A, B, C, D - clusters A, B, C, D; X-plots from conventional tracks recorded in the past (2014-2019), Y - plots from green tracks recorded in the present (2020), numbers represent numbers of localities - for explanation see Table 1

Slika 14: Dendrogram klastrske analize flore med robovi tramvajskih prog na različnih lokacijah (uporabili smo binarno razdaljo in povprečno metodo povezovanja). Legenda: A, B, C, D, - klastri A, B, C, D,; X - ploskve na konvencionalnih progah med leti 2014 in 2019, Y - ploskve na ozelenjenih progah leta 2020, številka predstavlja število lokacij - za razlago glej Tabelo 1 .

\section{Discussion}

The ruderal flora of tram and railway tracks consist of both, native and alien species. Non-native plant taxa are an important components of these habitats (Hansen \& Clevenerg, 2005; Kelcey \& Müller, 2011; Wiłkomirski et al., 2012; Zaliberová \& Májeková, 2014; Májeková et al., 2016; Denisow et al., 2017; Jehlík et al., 2017; Wrzesien \& Denisow, 2017). Our results from Bratislava confirmed this phenomenon. Both older, conventional tram tracks and newer green tram tracks host a relatively high proportion of alien species (Figures 7-8).

In both datasets, the older and the more recent, archaeophytes prevailed over neophytes and this pattern was found in both strict rail yard and tracksides (Figures 7-8). Findings of many authors, who have researched railways (Galera et al., 2014; Májeková and Limánek, 2016; Májeková et al., 2016; Jehlík et al., 2017) bring the same results as our study; archaeophytes were more abundant than neophytes. As both tram and railway tracks are examples of dry habitats with open vegetation, they both offer suitable conditions for the growth of archaeophytes (Chytrý et al., 2008). It is interesting that in Bratislava archaeophytes prevailed over neophytes not only on the strict rail yard, but also on tracksides (Figure 8), where vegetation is denser than on the strict rail yard. Nevertheless, tracksides still present dry habitat with relatively open vegetation compared to other city habitats, which could account for the high proportion of archaeophytes on tracksides.

The majority of studies from the urban environment which evaluate the changes in the representation of alien species find an increase of the number of alien species, mainly neophytes (Chocholoušková \& Pyšek, 2003; Lososová \& Simonová, 2008; Medvecká et al., 2009; Nobis et al., 2009; Gregor et al., 2012). Our study shows the same results for the trackside habitat (Figure 10a, b), but on the strict rail yard, the opposite pattern holds. Both the Sign test as well as the Wilcoxon two-sample test showed a significant decrease in the occurrence of archaeophytes and neophytes compared to the past (Figure $9 \mathrm{a}, \mathrm{b})$. In the presentation of our results, we have to take into account the fact that our study was done on specific tram track habitats and does not evaluate other urban habitats, while studies of other authors have researched a wider spectrum of habitats. Moreover, in our case, the habitat conditions changed significantly and in a universal direction, as conventional tram tracks were replaced by green ones. This difference could explain why the studies which are focused mainly on changes generate different results compared to ours.

From the total of the strict rail yard species, 72 taxa (the majority) saw a decline in frequency in comparison with past (Figure 5). The decrease in the frequency of the majority of total species number makes the decrease in frequency of the alien taxa group more probable. Moreover, not only the frequency of occurrence, but also the species numbers are lower than they were in the past (Figures 3, 7), a fact which could also have an impact on the results.

The most probable explanation for the decrease of the species numbers and frequencies on the strict rail yard seems to be a conversion of conventional tram tracks into green ones. Compared to the past (i.e. conventional tram tracks), green tram tracks host mainly planted succulents, which compete with spontaneously growing ruderal plants. Succulents planted on green tram tracks now occupy the major part of the habitat, and therefore only a few spontaneously growing ruderal plants can succeed. From this we can conclude that on the strict rail yard area of tram tracks, succulents represent strong competitors, as the numbers and frequency of occurrence of spontaneously growing ruderal plants on this habitat is lower than it was on the tracks without planted succulents (i.e. in the 
past), and that this also applies for spontaneously growing alien plants.

Another factor which could lead to the lower frequency of occurrence of ruderal species in present could be the fact that the green tram tracks were built in Bratislava only recently. As a result, this research could be done only in 2020. Therefore, the habitats studied could lack species from the later succession stages. In addtion, the substrate from before 2020 was removed when railway tracks were rebuilt. Underground organs of perennial species were removed by this process, so annual plants could dominate the first year. Also, the seed bank could be impoverished if the previous substrate was removed. The results of the explanatory analysis of the life forms agree with these ideas, as they revealed the increase of the therophytes and decrease of hemicryptophytes between old data (i.e. conventional tracks) and recent data (green tracks) (Figures 11-12).

Species such as Achillea millefolium and Cichorium intybus occur on the strict rail yard less frequently in the year 2020 than in the past and species such as Ballota nigra, Clematis vitalba, Elymus repens, Lolium perenne, Lotus corniculatus, Pastinaca sativa, Potentilla argentea, which were recorded in the past, did not occur on the strict rail yard of tram tracks in 2020 at all (Table 2). Most of these species are hemicryptophytes, which grow typically in the vegetation of the phytosociological classes Artemisietea vulgaris and Molinio-Arrhenatheretea, which emerge in the later succession stages. It is possible, than, that some spontaneously growing ruderal plants will emerge in the coming years, but the number of these species should not be high, as they will always have to compete with planted succulents.

The differences between conventional tracks (old dataset) and green tram tracks (recent dataset) were confirmed by the cluster analysis. The majority of clusters (Figures 13-14) were separated based on the period in which they had been recorded. A minority of clusters merge the old and more recent records, e.g. cluster B in the dendrogram of the records from tracksides, which could be caused by the fact that the clusters merge the old and more recent records from the same localities (Figure 14). The cluster analysis showed that the species composition in these particular plots remained similar, but that it did change on the majority of localities, which form other clusters.

Compared to conventional tracks, green tram tracks hosted fewer spontaneously growing ruderal 'weed' plant taxa (Figures 3-4), which are perceived as undesirable by city residents, unlike planted taxa on green tracks (Özgüner \& Kendle, 2006). However, the process of building green tram tracks can also carry risks. The number of ruderal species in 2020 is lower than it was in the past, but we have recorded some particular taxa such as Amaranthus blitoides, Carduus acanthoides, Cerastium fontanum subsp. vulgare, Geranium pyrenaicum, Oxalis dilenii, Rumex acetosella, Urtica dioica, Urtica urens growing directly on green tram tracks in the present and none of these species occurred in the ruderal flora of conventional tram tracks in the past (Table 2). The majority of the mentioned species are alien species in Slovakia. Propagules of some ruderal species, which were recorded only in the year 2020, could have been brought in with the construction material in the process of reconstruction of tram tracks. Construction sites are good environments for the spreading of alien species, as they present constantly disturbed habitats with many empty niches, and they experience strong disturbances (Chytrý et al., 2005; Simonová \& Lososová, 2008). Since the construction material is imported from foreign countries (Poland in our case), propagules of some alien plant taxa, as well as some potentially invasive, can be introduced into the new territories in this way.

Moreover, some of the species planted on green tram tracks (e.g. Sedum hispanicum, Sedum spurium) and their tracksides (e.g. Calendula officinalis, Cerastium tomentosum, Fagopyrum esculentum, Ligustrum ovalifolium, Malva moschata, Spiraea japonica) in Bratislava are listed as neophytes in the List of alien species of Slovakia (Medvecká et al. 2012).

Many authors (Reichard \& White, 2001; DehnenSchmutz et al., 2007; Hulme, 2011; Pyšek et al., 2012; Lehan et al., 2013; Pyšek et al., 2015; Perg et al., 2016; Mayer et al., 2017) have proven the trend of alien plants' escapes from cultivation (horticulture, botanical gardens etc.) and of becoming invasive in the future. Therefore, it follows that plants cultivated on tram tracks may also constitute a risk of being an source of alien, potentially invasive taxa.

From the aspect of the potential risk of plant invasion, the strict rail yard of green tram tracks covered by succulents turned out to be a biotope with lower risk than conventional tracks, as they hosted a lower number of spontaneously growing alien taxa, and their frequency of occurrence also was lower than on conventional tracks (Figures 7, 9a, b). However, they may still present a risk of being a pool of planted alien potentially invasive taxa. But the strict rail yard of conventional tracks presents even higher risk, as this habitat hosted a higher number of alien taxa, which occurred more frequently (Figures 7 , $9 \mathrm{a}, \mathrm{b})$ than on the strict rail yard of green tracks.

Covering the tracksides of green tracks with ornamental non-succulent plants did not prove to be a very good choice, as they hosted more alien plant taxa, and these also occurred more frequently than on conventional tracksides (Figures 8, 10a, b). 
Tram and railway habitats can serve as the refuge areas for endangered and rare species (Májeková et al., 2014; Májeková \& Limánek, 2016). Results of our study revealed, that rare taxa such as Filago arvensis, Misopates orontium, and Petrorhagia saxifraga, which grew on conventional tram tracks of Bratislava in the past, were not recorded on green tracks in 2020. We also recorded a lower total number of spontaneously growing vascular taxa as well as bryophyte taxa on green tracks than on conventional tracks (Figures 3-4, Tables 2-3). The maintenance of the highest biodiversity possible should be one of the priorities in the efforts of environmentalists. Bryophytes have many beneficial functions for the urban ecosystem (e.g. they contribute to biodiversity, improve microclimatic conditions, accumulate pollutants and heavy metals, increase humidity, serve as a shelter for invertebrates etc.) (Haines \& Renwick, 2009; Bahuguna et al., 2013; Jiang et al., 2018). Therefore, from the perspective of biodiversity, the green tracks of Bratislava do not appear to be a very good solution, but we must remember, that only the number of spontaneously growing taxa was assessed. If we also include the planted taxa into the analyses, the species number would be higher and biotope would not present itself as species-poor. Moreover, it is possible that some species (including bryophytes) might recolonize these habitats. Nevertheless, several other authors have confirmed that unmanaged or lightly managed urban areas have higher biodiversity than intensively managed green areas (Säumel et al., 2016; Unterweger et al., 2017). This is not related only to the plant biodiversity, but also to the diversity of animals. For example, Walker et al. (2017) suggest that demolition activities, which are connected with the introduction of green spaces in cities do not increase avian species richness.

On the other hand, Özgüner and Kendle (2006) proved that from an aesthetic point of view, managed green spaces are more valued by the majority of city residents than places covered by more diverse spontaneously growing ruderal vegetation.

The question of whether it is better to leave tram tracks and other urban habitats to self-development or to maintain them remains a matter of worldwide discussion. Our conclusion is that, at least in Bratislava, there are positive and negative aspects of both green tracks and the conventional ones. It must be remembered that we can not consider the conventional tracks as habitat which has been left entirely to self-development, as some controlled human intervention (e.g. trackside mowing) takes place here from time to time. On the other hand, controlled interventions on green tracks were more comprehensive, as these areas have been covered by a completely new spectrum of planted species. The upside of green tracks in Bratislava is that the tracks were covered with carpets of many evergreen Sedum species, which have only low ongoing maintenance requirements and thus require less human interventions. The resulting environmental and economic advantages of Sedum green tracks have been noted e.g. by Schreiter (2010). However, there is a negative side with respect to Sedum tracks; namely, that these do little to contribute to biodiversity, a fact which is also confirmed in a technical report from Toronto (Eglinton, 2014). Sikorski et al. (2018) have stated that it was not planted species, but mostly spontaneously growing plants which have contributed substantially to the greenness coverage of green tracks in Warsaw. The authors of this study suggested that low-maintenance green tram tracks undergoing spontaneous succession may be a good environmental solution, but they admit, that such strategy requires further studies. Another advantage of lowmaintenance green tracks is the fact that they present an economically better solution than intensively maintained green tracks (Sikorski et al., 2018).

Based on our results we suggest attempting to implement more native species into green carpets on tram tracks in Bratislava to increase their biodiversity and eliminate the risk of alien species invasions. Many native species have high aesthetic value and could prosper on tram tracks' biotope. This idea needs to be considered in advance and the spectrum of these species should be compiled by specialists (technicians, engineers, botanists, environmentalists etc.). A similar approach has been taken on some sections of Vienna's tram tracks (Steckler et al., 2012), where particular attention has been paid to the ecological aspects of green tracks. In this effort, self-sufficient salt and drought resistant flowering plants of native origin were added into commercial mixtures of planted species.

All species planted in tram tracks are presumably treated by breeding measures. With the taxa having near relatives within the local flora genetic interactions could occur (e.g. hybridizing, backcrossing) which may be able to change the local gene pool. Greening process which use at least partly nonresident species could be counterproductive. In Germany the concept of "local seed and plants“ was developed, which propose to carry out greening of traffic infrastructure only with seeds locally yielded and aggrandized (Prasse et al., 2010). We also recommend to rather avoid to use alien taxa and try to use more autochthonous ornamental species in the greening process of tram tracks. These should be such native species which are no able to change lokal genetic pool dramatically and which can also exist in the environmental conditions of tram tracks, e.g. Sedum acre, S. album. 
Green spaces and green tram tracks should serve as areas, which help to maintain the biodiversity of cities (Sikorski et al., 2018), but invasive species, which can potentially arise due to the construction of green areas, could contribute to the reduction of biodiversity at the end. Our study revealed the decrease of the total number of species and the decrease of the frequency of occurrence of archaeophytes and neophytes on the strict rail yard and the increase on the tracksides. Although the recent research was only conducted in 2020, it presents an important first view of the situation of plant dynamics on tram tracks and an interesting comparison between conventional and green tram track habitat. Fundamental changes during the next years are likely to expect. The study of tram track habitats of Bratislava shall continue in next years.

\section{Acknowledgements}

We thank Dr. George Scott Burgess for English grammar proofreading of the manuscript. We are grateful to Doc. Katarína Mišíková, PhD. for identification of bryophytes. This study was supported by the Operation Program of Research and Innovation for the project: Advancing University Capacity and Competence in Research, Development and Innovation, ITMS2014+: 313021X329, cofinanced by the European Regional Development Fund. The research was also supported by the APVV-18-0052, APVV-17-0066, and the Grant Agency VEGA, Grant No. 1/0767/17. We are grateful to Greenfond Polska Sp z o.o., which has provided us with the list of Sedum species of green tram tracks of Bratislava.

Alena Rendeková (D) https://orcid.org/0000-0003-2083-4929
Karol Mičieta (D) https://orcid.org/0000-0003-0676-3933
Michal Hrabovský (D) https://orcid.org/0000-0002-7834-4167
Eva Zahradníková (D) https://orcid.org/0000-0002-0632-6146

\section{References}

Andreucci, M. B. (2013). Progressing green infrastructure in Europe. WIT transactions on ecology and the environment 179. The Sustainable City, 8(1), 413-422. https://doi.org/10.2495/SC130351

Bahuguna, Y. M., Gairola, S., Semwal, D. P., Uniyal, P. L., \& Bhatt, A. B. (2013). Bryophytes and ecosystem. In R. K. Gupta, \& M. Kumar (Eds.), Biodiversity of lower plants (pp. 279-296). IK International Publishing House Pvt. Ltd.

Banister, D. (2010). Sustainable urban development and transport - a Eurovision for 2020. Transport Reviews, 20(1), 113-130. http://doi. org/10.1080/014416400295365

Brandes, D. (1983). Flora und Vegetation der Bahnhöfe Mitteleuropas. Phytocoenologia, 11, 31-115. https://doi.org/10.1127/ phyto/11/1983/31

Brandes, D. (1984). Flora und Vegetation von Bahnhöfen im nördlichen Deutschland. Acta Botanica Slovaca Academiae Scientiarum Slovacae Ser A, suppl. 1, 9-16.

Brandes, D. (1993a). Eisenbahnanlagen als Untersuchungsgegenstand der Geobotanik. Tuexenia, 13, 415-444.

Brandes, D. (1993b). Zur Ruderalflora von Verkehrsanlagen in Magdeburg. Floristische Rundbriefe, 27(1), 50-54.

Brandes, D. (2002a). Zur Flora des Bahnhofs Köstchach-Mauthen (Kärnten, Österreich). Retrieved October 4, 2020, from http://www. ruderal-vegetation.de/epub/koetschach.pdf. https://doi.org/10.13140/ RG.2.1.1167.4080

Brandes, D. (2002b). Vascular flora of the Lüchow railway station (Lower Saxony, Germany). Retrieved October 4, 2020, from http://www. ruderal-vegetation.de/epub/vascular.pdf

Brandes, D. (2003). Flora und Vegetation des Hauptbahnhofs Magdeburg. Retrieved October 5, 2020, from http://www.ruderalvegetation.de/epub/hbf_md.pdf

Brandes, D. (2004a). Exkursionsziel Eisenbahnbrache? Der unerwartete Artenreichtum von innerstädtischen Eisenbahnflächen. Retrieved October 7, 2020, from http://www.ruderal-vegetation.de/epub/ eisenbahnbrache.pdf

Brandes, D. (2004b). Flora des ehemaligen Bahnhofs Dömitz (Elbe). Retrieved October 6, 2020, from http://www.ruderal-vegetation.de/ epub/bf_doemitz.pdf

Brandes, D. (2004c). Zur Flora des Bahnhofs Perleberg (Brandenburg). Retrieved November 10, 2020, from http://www.ruderal-vegetation. de/epub/bahnhof_perleberg.pdf

Brandes, D. (2004d). Zur Flora des Bahnhofs Halberstadt. Retrieved December 18, 2020, from http://www.ruderal-vegetation.de/epub/ bahnhof_halberstadt.pdf

Brandes, D. (2005a). Die Flora der Stadtbahn Braunschweig: Stadtbahnen als einfaches Modell für die Besiedlung eines isolierten Bahnnetzes durch Pflanzen. Retrieved Nevember 12, 2020, from https://publikationsserver.tu-braunschweig.de/receive/dbbs_ mods_00001669

Brandes, D. (2005b). Kormophytendiversität innerstädtischer Eisenbahnanlagen. Tuexenia, 25, 269-284. 
Brandes, D. (2008). Bibliographie zur Eisenbahnvegetation. Retrieved October 18, 2020, from http://www.digibib.tu-bs. de/?docid $=00021885$

Burgin, S. (2016). What about biodiversity? Redefining urban sustainable management to incorporate endemic fauna with particular reference to Australia. Urban Ecosystems, 1(9), 669-678. https://doi. org/10.1007/s11252-015-0522-0

Cameron, R. W. F., Brindley, P., Mears, M., McEwan, K., Ferguson, F., Sheffield, D., Jorgensen, A., Riley, J., Goodrick, J., Ballard, L., \& Richardson, M. (2020). Where the wild things are! Do urban green spaces with greater avian biodiversity promote more positive emotions in humans? Urban Ecosystems, 23, 301-317. https://doi.org/10.1007/ s11252-020-00929-z

Castro, A. V., Porrini, D. P., Lupo, S., \& Cicchino, A. C. (2020). Minimal stories in Southeast Buenos Aires grasslands: carabid beetle biodiversity throughout an urban-rural gradient. Urban Ecosystems, 23, 331-343. 7https://doi.org/10.1007/s11252-019-00925-y

Chocholoušková, Z., \& Pyšek, P. (2003). Changes in composition and structure of urban flora over 120 years: a case study of the city of Plzeň. Flora, 198(5), 366-376. https://doi.org/10.1078/0367-2530-00109

Chytrý, M., Pyšek, P., Tichý, L., Knollová, I., \& Danihelka, J. (2005). Invasions by alien plants in the Czech Republic: a quantitative assessment across habitats. Preslia, 77, 339-354.

Chytrý, M., Maskell, L. C., Pino, J., Pyšek, P., Vilá, M., Font, X., \& Smart, S. M. (2008). Habitat invasions by alien plants: a quantitative comparison among Mediterranean, subcontinental and oceanic regions of Europe. Journal of Applied Ecology, 45(2), 448-458. https://doi. org/10.1111/j. 1365-2664.2007.01398.x

Chytrý, M., Danihelka, J., Kaplan, Z., Wild, J., Holubová, D., Novotný, P., Řezníčková, M., Rohn, M., Dřevojan, P., Grulich, V., Klimešová, J., Lepš, J., Lososová, Z., Pergl, J., Sádlo, J., Šmarda, P., Štěpánková, P., Tichý, L., Axmanová, I., Bartušková, A., Blažek, P., Chrtek, J. Jr., Fischer, F. M., Guo, W.-Y., Herben, T., Janovský, Z., Konečná, M., Kühn, I., Moravcová, L., Petřík, P., Pierce, S., Prach, K., Prokešová, H., Štech, M., Těšitel, J., Těsitelová, T., Večeřa, M., Zelený, D., \& Pyšek, P. (2021). Pladias Database of the Czech Flora and Vegetation. Preslia, 93, 1-87.

Dehnen-Schmutz, K., Touza, J., Perrings, C., \& Williamson, M. (2007). The horticultural trade and ornamental plant invasions in Britain. Conservation Biology, 21, 224-231. http://doi.org/10.1111/ j.1523-1739.2006.00538.x

Denisow, B., Wrzesień, M., Mamchur, Z., \& Chuba, M. (2017). Invasive flora within urban railway areas: a case study from Lublin (Poland) and Lviv (Ukraine). Acta Agrobotanica, 70(4), 1727. https:// doi.org/10.5586/aa.1727

Eglinton, L. R. T. (2014). Green trackway precedents study, technical report. Retrieved October 12, 2020, from http://citeseerx.ist.psu.edu/ viewdoc/download?doi=10.1.1.567.6008\&rep=rep $1 \&$ type $=$ pdf

Eliáš, P. (1979). Zriedkavejšie rastliny železničných komunikácií na západnom Slovensku I. Biológia, 34, 67-70.

Eliáš, P. (1981). Zriedkaveǰ̌ie rastliny železničných komunikácií na západnom Slovensku II. Biológia, 36, 73-77.

Feráková, V., \& Jarolímek, I. (2011). Bratislava. In: J. K., Kelcey, \& N., Müller (Eds.), Plants and habitats of European cities (pp. 79-129). Springer. https://doi.org/10.1007/978-0-387-89684-7_4
Galera, H., Sudnik-Wójcikowska, B., Wierzbicka, M., \& Wiłkomirski, B. (2012). Directions of changes in the flora structure in the abandoned railway areas. Ecological Questions, 16, 29-39. https://doi. org/10.2478/v10090-012-0003-5

Galera, H., Sudnik-Wójcikowska, B., Wierzbicka, M., Jarzyna, I., \& Wiłkomirski, B. (2014). Structure of the flora of railway areas under various kinds of anthropopression. Polish Botanical Journal, 59, 1-10. https://doi.org/10.2478/pbj-2014-0001

Gregor, T., Bönsel, D., Starke-Ottich, I., \& Zizka, G. (2012). Drivers of floristic change in large cities - a case study of Frankfurt/main (Germany). Landscape and Urban Planning, 104, 230-237. https://doi. org/10.1016/j.landurbplan.2011.10.015

Haines, W. P., \& Renwick, J. A. A. (2009). Bryophytes as food: Comparative consumption and utilization of mosses by a generalist insect herbivore. Entomologia Experimentalis et Applicata, 133(3), 296-306. http://doi.org/10.1111/j.1570-7458.2009.00929.x

Hansen, M. J., \& Clevenerg, A. P. (2005). The influence of disturbance and habitat on the presence of non-native plant species along transport corridors. Biological Conservation, 125(2), 249-259. https://doi.org/10.1016/j.biocon.2005.03.024

Henze, H. J., \& Model, N. (2006). Ability of plant-based surface technology to improve urban water cycle and mesoclimate. Urban Forestry \& Urban Greening, 4, 145-158. https://doi.org/10.1016/j. ufug.2005.12.004

Hohla, M., Kleesadl, G., \& Melzer, H. (2000). Neues zur Flora des oberösterreichischen Bahnanlagen - mit Einbeziehung einiger grenznaher Bahnhöfe Bayerns. Beiträge zur Naturkunde Oberösterreichs, 9, 191-250.

Hohla, M., Kleesadl, G., \& Melzer, H. (2002). Neues zur Flora der oberösterreichischen Bahnanlagen - mit Einbeziehung einiger Bahnhöfe Bayerns - Fortsetzung. Beiträge zur Naturkunde Oberösterreichs, 11, 507-578.

Horák, J. (2016). Suitability of biodiversity-area and biodiversity-perimeter relationships in ecology: a case study of urban ecosystems. Urban Ecosystems, 19, 131-142. https://doi.org/10.1007/s11252-015-0492-2

Hrnčiarová, T., Izakovičová, Z., Pauditšová, E., Krnáčová, Z., Štefunková, D., Dobrovodská, M., Kalivodová, E., Moyzeová, M., Špulerová, J., \& Popovičová-Waters, J. (2006). Krajinnoekologické pomery rozvoja Bratislavy. Veda.

Hulme, P. E. (2011). Addressing the threat to biodiversity from botanic gardens. Trends in Ecology \& Evolution, 26, 168-174. http:// doi.org/10.1016/j.tree.2011.01.005

Jiang, Y., Fan, M., Hu, R., Zhao, J., \& Wu, Y. (2018). Mosses are better than leaves of vascular plants in monitoring atmospheric heavy metal pollution in urban areas. International Journal of Environmental Research and Public Health, 15(6), 1105. https://doi.org/10.3390/ ijerph15061105

Jarolímek, I., Šibík, J., Hegedüšová, K., Janišová, M., Kliment, J., Kučera, P., Májeková, J., Michálková, D., Sadloňová, J., Šibíková, J., Škodová, I., Uhliríová, J., Ujházy, K., Ujházyová, M., Valachovič, M., \& Zaliberová, M. (2008). A list of vegetation units of Slovakia. In I. Jarolímek, \& J. Šibík (Eds.), Diagnostic, constant and dominant species of the higher vegetation units of Slovakia (pp. 295-329). Veda.

Jehlík, J., \& Dostálek, J. (2008). Influence of railway transport in the south-east of Slovakia on formation of adventive flora in Central Europe. Biodiversity Research and Conservation, 11-12, 27-32. 
Jehlík, V., Zaliberová, M., \& Májeková, J. (2017). The influence of the eastern migration route on the Slovak flora - a comparison after 40 years. Tuexenia, 37, 313-332. https://doi.org/10.14471/2016.37.023

Kelcey, J-K., \& Müller, N. (2011): Plants and habitats of European cities. Springer.

Kumar, A., \& Verma, A. K. (2017). Biodiversity loss and its ecological impact in India. International Journal of Biological Sciences, 8(2), 156-160.

Lehan, N. E., Murphy, J. R., Thorburn, L. P., \& Bradley, B. A. (2013). Accidental introductions are an important source of invasive plants in the continental United States. American Journal of Botany, 100, 1287-1293. http://doi.org/10.3732/ajb.1300061

Lososová, Z., \& Simonová, D. (2008). Changes during the twentieth century in species composition of synanthropic vegetation in Moravia (Cezch Republic). Preslia, 80, 291-305.

Májeková, J., \& Limánek, J. (2016). Diverzita flóry železničných staníc na trati Poprad - Plaveč (východné Slovensko). Bulletin Slovenskej botanickej spoločnosti, 38(1), 37-45.

Májeková, J., Jehlík, V., \& Zaliberová, M. (2016). Railway stations vs. thermophilous species (example from eastern Slovakia). Thaiszia Journal of Botany, 26(2), 173-188.

Májeková, J., Letz, D. R., Slezák, M., Zaliberová, M., \& Hrivnák, R. (2014). Rare and threatened vascular plants of the railways in Slovakia. Biodiversity Research and Conservation, 35, 75-85.

Májeková, J., Zaliberová, M., Andrik, E., Protopopova, V., Shevera, M., \& Ikhardt, P. (2021). A comparison of the flora of the Chop (Ukraine) and Cierna nad Tisou (Slovakia) border railway stations. Biologia, 76, 1969-1989. https://doi.org/10.2478/s11756-02000592-x

Mayer, K., Haeuser, E., Dawson, W., Essl, F., Kreft, H., Pergl, J. Pyšek, P., Weigelt, P., Winter, M., Lenzner, B., \& van Kleunen, M. (2017). Naturalization of ornamental plant species in public green spaces and private gardens. Biological Invasions, 19, 3613-3627. https://doi.org/10.1007/s10530-017-1594-y

Medvecká, J., Jarolímek, I., \& Zaliberová, M. (2009). Dynamics and distribution of neophytes in the Horná Orava Region (North Slovakia). Hacquetia, 8(2), 147-58. https://doi.org/10.2478/v10028-009-0009-8

Medvecká, J., Kliment, J., Májeková, J., Halada, L., Zaliberová, M., Gojdičová, E., Feráková, V., \& Jarolímek, I. (2012). Inventory of alien species of Slovakia. Preslia, 84, 257-309.

Müller, C., Kuppelwieser, H., Arx, R., \& Beyeler, R. (2001). Vegetation Control on Railway Tracks and Grounds. Swiss Federal Railways (SBB/ CFF/FFS), Swiss Agency for the Environment, Forests and Landscape (SAEFL), Federal Transport Office (BAV).

Niemi, A. (1969). On the railway vegetation and flora between Esbo and Inga, S. Finland. Acta Botanica Fennica, 83, 2-29.

Nobis, M. P., Jaeger, J. A. G., \& Zimmermann, N. E. (2009). Neophyte species richness at the landscape scale under urban sprawl and climate warming. Diversity and Distributions, 15(6), 928-939. https://doi.org/10.1111/j.1472-4642.2009.00610.x

Özgüner, H., \& Kendle, A. D. (2006). Public attitudes towards naturalistic versus designed landscapes in the city of Sheffield (UK). Landscape and Urban Planning, 74(2), 139-157. http://doi. org/10.1016/j.landurbplan.2004.10.003
Pergl, J., Sádlo, J., Petř́ík, P., Danihelka, J., Chrtek, Jr., Hejda, M., Moravcová, L., Perglová, I., Štajerová, K., \& Pyšek, P. (2016). Dark side of the fence: ornamental plants as a source of wildgrowing flora in the Czech Republic. Preslia, 88, 163-184.

Pfautsch, S., \& Howe, V. (2018). Green Track for Parramatta Light Rail: A Review. Western Sydney University. https://doi. org/10.26183/5c05fc021efb3

Prasse, P., Kunzmann, D., \& Schröder, R. (2010). Entwicklung und praktische Umsetzung naturschutzfachlicher Mindestanforderungen an einen Herkunftsnachweis für gebietseigenes Wildpflanzensaatgut krautiger Pflanzen Abschlussbericht. Abschlussbericht: DBU-Projekt. Retrieved July 7, 2021, from https://www.dbu.de/OPAC/ab/DBU-AbschlussberichtAZ-23931.pdf

Provendier, D., \& Damas, O. (2010). Urban and suburban areas covered with grass: functional importance and prospects for innovations. Fourrages, 203, 205-211.

Pyšek, P., Danihelka, J., Sádlo, J., Chrtek, J Jr., Chytrý, M., Jarošík, V., Kaplan, Z., Krahulec, F., Moravcová, L., Pergl, J., Štajerová, K., \& Tichý, L. (2012). Catalogue of alien plants of the Czech Republic (2nd edition): checklist update, taxonomic diversity and invasion patterns. Preslia, 84, 155-255.

Pyšek, P., Manceur, A. M., Alba, C., McGregor, K. F., Pergl, J., Śtajerová, K., Chytrý, M., Danihelka, J., Kartesz, J., Klimešová, J., Lučanová, M., Moravcová, L., Nishino, M., Sádlo, J., Suda, J., Tichý, L., \& Kühn, I. (2015). Naturalization of central European plants in North America: species traits, habitats, propagule pressure, residence time. Ecology, 96, 762-774. http://doi.org/10.1890/14-1005.1

R Core Team. (2018). R: a language and environment for statistical computing. R Foundation for Statistical Computing, Vienna, Austria. (Retrieved 3 November 2020) https://www.R-project.org/.

Reichard, S. H., \& White, P. (2001). Horticulture as a pathway of invasive plant introductions in the United States. BioScience, 51 103-113. http://doi.org/10.1641/0006-3568(2001)051\%5B0103:HA APOI\%5D2.0.CO;2

Rendeková, A., Mičieta, K., Randáková, Z., Ballová, D., Eliašová, M., \& Miškovic, J. (2020). Flora of the tram tracks of Bratislava. Urban Ecosystems, 23, 875-891. https://doi.org/10.1007/s11252-020-00952-0

Renterghemi, T., Forssén, J., Attenborough, K., Jean, P., Defrance, J., Hornikx, M., \& Kang, J. (2015). Using natural means to reduce surface transport noise during propagation outdoors. Applied Acoustics, 92, 86-101. http://doi.org/10.1016/j.apacoust.2015.01.004

Säumel, I., Weber, F., \& Kowarik, I. (2016). Toward livable and healthy urban streets: roadside vegetation provides ecosystem services where people live and move. Environmental Science \& Policy, 62, 24-33. http://doi.org/10.1016/j.envsci.2015.11.012

Schreiter, H. (2010). Green tram tracks - The advantages of implementing vegetation systems in tram tracks. Final Conference Urban Track. Retrieved November 3, 2020, from https://nacto.org/wpcontent/uploads/2016/04/3-7_Green-Tram-Tracks-The-Advantages-ofImplementing-Vegetation-Systems-in-Tram-Tracks_2010.pdf

Schreiter, H., \& Kappis, C. (2013a). Effect and function of green tracks. Retrieved November 9, 2020, from http://www.gruengleisnetzwerk.de/ images/downloads/effects.pdf

Schreiter, H., \& Kappis, C. (2013b). Green tram track. Effect \& functions. World Green Infrastructure Congress. Retrieved December 2, 2020, from https://uploads-ssl.webflow.com/5b6c9d193d9b84072f 6f9cd0/5c6d1afed51c774e0187e3c5_poster1301.pdf 
Sikorska, D., Laszkiewicz, E., Krauze, K., \& Sikorski, P. (2020). The role of informal green spaces in reducing inequalities in urban green space availability to children and seniors. Environmental Science \& Policy, 108, 144-154. http://doi.org/10.1016/j.envsci.2020.03.007

Sikorski, P., Wińska-Krysiak, M., Chormański, J., Krauzec, K., Kubackaa, K., \& Sikorska, D. (2018). Low-maintenance green tram tracks as a socially acceptable solution to greening a city. Urban Forestry \& Urban Greening, 35, 148-164. https://doi.org/10.1016/j. ufug.2018.08.017

Simonová, D., \& Lososová, Z. (2008). Which factors determine plant invasions in man-made habitats in the Czech Republic? Perspectives in Plant Ecology Evolution and Systematics, 10(2), 89-100.

Steckler, P., Klug, B., Gasser, F., \& Wehr, W. (2012). Green track - environmental performance evaluation for 'green' tramway superstructure. Road and Rail Infrastructure, II, 683-691.

Sudnik-Wójcikowska, B., Galera, H., Suska-Malawska, M., Staszewski, T., \& Wiłkomirski, B. (2014). Specyfika grupy najpospolitszych gatunków we florze wybranych silnie skażonych odcinków torowisk kolejowych w północno-wschodniej Polsce (Mazury i Podlasie). Monitoring Środowiska Przyrodniczego, 15, 59-73.

Suominen, J. (1969). The vegetation of railways and adjacent storage areas in Finland. Annales Botanici Fennici, 6(4), 353-367.

Tret'yakova, A. S. (2010). The role of railroads in the formation of synanthropic flora in the middle Urals. Russian Journal of Ecology, 41(2), 123- 128. https://doi.org/10.1134/S1067413610020037

The Plant List (2013). Version 1.1. Retrieved December 12, 2020 , from http://www.theplantlist.org/. (accessed 12 December 2020)

Unterweger, P. A., Schrode, N., \& Betz, O. (2017). Urban nature: perception and acceptance of alternative green space management and the change of awareness after provision of environmental information. A chance for biodiversity protection. Urban Science, 1(3), 24. http:// doi.org/10.3390/urbansci1030024

Vasas, V., Magura, T., Jordán, F., \& Tóthmérész, B. (2009). Graph theory in action: evaluating planned highway tracks based on connectivity measures. Landscape Ecology, 24, 581-586. http://doi. org/10.1007/s10980-009-9346-8

Wagner, I., Krauze, K., \& Zalewski, M. (2013). Błękitne aspekty zielonej infrastruktury. Zrównoważony Rozwój-Zastosowania, 4 , $145-155$.
Walker, C. M., Colton Flynn, K., Ovando-Montejo, G. A., Ellis, E. A., \& Frazier, A. E. (2017). Does demolition improve biodiversity? Linking urban green space and socioeconomic characteristics to avian richness in a shrinking city. Urban Ecosystems, 20, 1191-1202. https:// doi.org/10.1007/s11252-017-0671-4

Wierzbicka, M., Galera, H., Sudnik-Wójcikowska, B., \& Wiłkomirski, B. (2014). Geranium robertianum L., plant form adapted to the specific conditions along railway: "railway-wandering plant". Plant Systematics and Evolution, 300, 973-985. http://doi. org/10.1007/s00606-013-0936-1

Wiłkomirski, B., Galera, H., Sudnik-Wójcikowska, B., Staszewski, T., \& Malawska, M. (2012). Railway tracks - habitat conditions, contamination, floristic settlement - a review. Environment and Natural Resources Research, 1(2), 86-95. https://doi.org/10.5539/enrr. $\mathrm{v} 2 \mathrm{n} 1 \mathrm{p} 86$

Williams, N. S. G., Schwartz, M. W., Vesk, P. A., McCarthy, M. A., Hahs, A. K, Clemants, S. E., Corlett, R. T., Duncan, R. P., Norton, B. A., Thompson, K., \& McDonnell, M. J. (2009). A conceptual framework for predicting the effects of urban environments on floras. Journal of Ecology, 97, 4-9. https://doi.org/10.1111/j.13652745.2008.01460.x

Woźnica, P., Urbisz, A., Urbisz, A., \& Franiel, I. (2016). Tram tracks as specific anthropogenic habitats for the growth of plants. PeerJ Preprints, 4. Article e2606v1. https://peerj.com/preprints/2606.pdf

Wrzesień, M., \& Denisow, B. (2017). Factors responsible for the distribution of invasive plant species in the surroundings of railway areas. A case study from SE Poland. Biologia, 72(11), 1275-1284. https://doi.org/10.1515/biolog-2017-0146

Wrzesień, M., Denisow, B., Mamchur, Z., Chuba, M., \& Resler, I. (2016). Composition and structure of the flora in intra-urban railway areas. Acta Agrobotanica, 69(3), 1666. https://doi.org/10.5586/aa.1666

Zaliberová, M., \& Májeková, J. (2014). Poznámky k prvému nálezu Geranium purpureum Vill. na Slovensku a rozš́renie druhu na železničných staniciach Záhoria (západné Slovensko). Bulletin Slovenskej botanickej spoločnosti, 36(2), 223-232.

Zube, E. H. (1995). Greenways and the US National Park system. Landscape and Urban Planning, 33, 17-25. http://doi. org/10.1016/0169-2046(94)02011-4 